\title{
ENSO impacts on regional water management: case study of the Edwards Aquifer (Texas, USA)
}

\author{
Chi-Chung Chen ${ }^{1, * *}$, Dhazn Gillig ${ }^{2, * *}$, Bruce A. McCarl ${ }^{3, *, * *}$, R. Lynn Williams ${ }^{4}$ \\ ${ }^{1}$ Department of Applied Economics, National Chung-Hsing University, Taichung 402, Taiwan \\ ${ }^{2}$ American Express, Phoenix, Arizona 85021, USA \\ ${ }^{3}$ Department of Agricultural Economics, Texas A\&M University, College Station, Texas 77843, USA \\ ${ }^{4}$ Department of Agricultural Economics, California State University, Fresno, California 93740, USA
}

\begin{abstract}
This study investigates the water management actions required for, and regional benefits of, conditioning Edwards Aquifer water and agricultural management on the phases of El Niño-Southern Oscillation (ENSO), using data on ENSO frequency from 1970 to 1996. Water management adjustments would involve changes in agricultural crop mixes and urban water use to exploit seasonal climatic changes associated with ENSO. The value of ENSO-dependent management ranges from $\$ 1.1$ to $\$ 3.5$ million $\mathrm{yr}^{-1}$, depending on initial water level elevations in the aquifer. Exploitation of ENSO events has the potential to help offset the costs of diminishing regional pumping due to legislative mandates.
\end{abstract}

KEY WORDS: ENSO - Water management · Edwards Aquifer

\section{INTRODUCTION}

The El Niño-Southern Oscillation (ENSO) phenomenon is based on changes in the Eastern Tropical Pacific ocean-atmosphere system that contribute to climate shifts around the world (National Oceanic and Atmospheric Administration, Climatic Diagnostics Center; www.cdc.noaa.gov/ENSO/enso.kd.html, and www. ncdc.noaa.gov/ol/climate/elnino/elnino.html). ENSO and La Niña phases contribute to temperature and precipitation variation in the United States. Wolter et al. (1999) found that the greatest statistically significant relationship between ENSO incidents and seasonal temperatures across large areas of the USA occurred in winter and spring. They also found that El Niño and La Niña conditions substantially alter the probability of very warm and very cold seasons. One region that exhibits significant ENSO-related climate variations is the SW USA (Gershunov 1998, Cayan et al. 1999). In this relatively arid region, ENSO phases are associated with substantial precipitation variation, and with drought during the La Niña phase.
Substantial effort has been invested into recognizing the ENSO phase late in the calendar year (typically by November). This information could enable SW USA water agencies and municipalities to make proactive management adjustments. We examined the benefits of using ENSO phase information for regional water supply system management in the context of the USA San Antonio Edwards Aquifer region (SAEA) in Texas (see McCarl et al. 1998, for a description of the region).

\section{CHARACTERISTICS OF THE EDWARDS AQUIFER}

The Edwards Aquifer (EA) underlies the SAEA and provides water to more than 2 million people, satisfying agricultural, municipal, industrial, recreational, and environmental interests. Water from the EA is discharged through springs and wells. About $37 \%$ of SAEA pumping is agricultural, mainly in the western part, and $63 \%$ is by municipal and industrial users, mainly in the east, especially in the heavily populated 

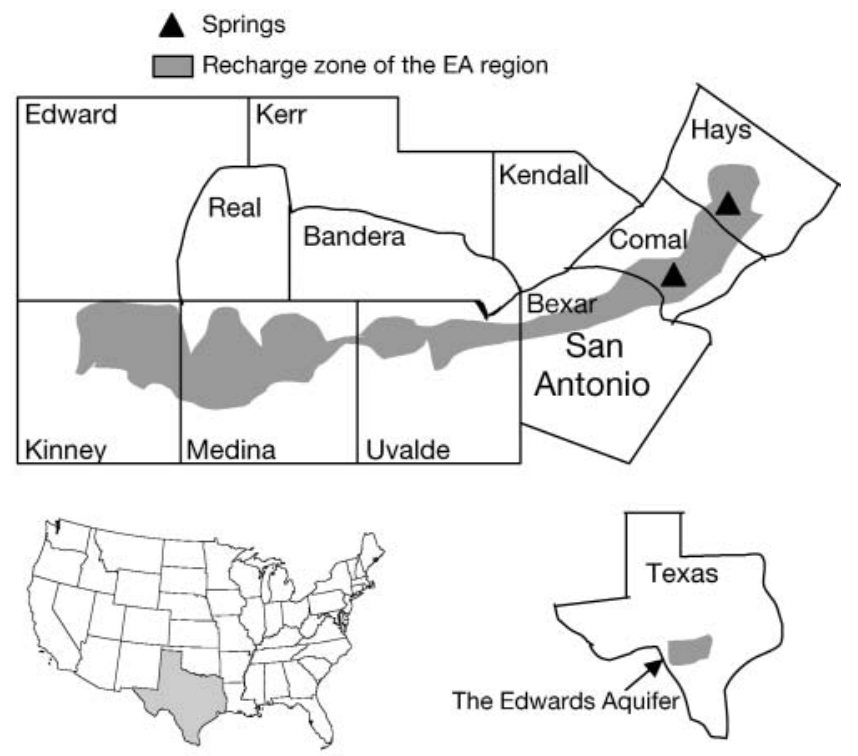

Fig. 1. Hydrological boundaries of the Edwards Aquifer (EA) region

San Antonio area (Fig. 1). The EA also supports Comal and San Marcos Springs, which provide habitat for endangered species (Longley 1992). Flows in these springs are sensitive to EA water levels. The EA discharges and recharges rapidly, as exemplified by a Bexar County indicator well (EA Authority Well J-17, located in San Antonio and used since 1956 to provide a summary measure of EA elevation; see Eckhardt G: www.edwardsaquifer.net/j17.html). Water levels at Well J-17 reached a record high elevation of $213 \mathrm{~m}$ in 1987, but after 2 yr of moderately low recharge with cumulative pumping less than cumulative recharge, the elevation dropped to $191 \mathrm{~m}$ in 1989, while Comal Springs nearly dried up.

The EA is centrally managed by the Edwards Aquifer Authority (www.edwardsaquifer.org/), which must manage the aquifer to ensure an adequate supply to the regional users as well as to maintain spring flow (Texas State Legislature, Senate Bill 1477, 1993).

\section{ENSO EVENTS AND RECHARGE OF THE EDWARDS AQUIFER}

There are many methods for classifying ENSO events, e.g. using sea surface temperature (SST) anomalies, sea surface air pressure differences across the Pacific, or a combination of these together with other weather parameters. This study used an ENSO characterization based on the October value of the 5 mo moving average of the SST anomaly in the tropical Pacific region $\left(4^{\circ} \mathrm{S}\right.$ to $4^{\circ} \mathrm{N}$ latitude, 150 to $90^{\circ} \mathrm{W}$ longitude), constructed by the Japan Meteorological Agency (www.kishou.go.jp/english/activities/observation/obs 5.html). The SST is used to classify ENSO events via the method developed by National Oceanic and Atmospheric Administration, Climate Diagnostics Center, commonly used in the USA (Climate Prediction Center). This method identifies 3 phases: warm (El Niño), cold (La Niña), or neutral (see the Queensland, Australia, Government Long Paddock website, available at: www.longpaddock.qld.gov.au/).

SAEA water supply depends on EA recharge, which in turn depends on precipitation and temperature. Thus, SAEA water availability is likely to be influenced by ENSO phases if they are associated with changes in precipitation and temperature. We characterized regional historical EA recharge estimates from 1970 to 1996 (United States Geological Survey, Recharge to and discharge from the Edwards Aquifer in the San Antonio Area, Texas, Austin, TX, various issues; the 1997 report is available at: http:// tx.usgs.gov/) and associated climate events into the 3 different phase groupings; 6 years fall into the El Niño phase $(1972,1976,1982,1986,1987,1991)$, 4 years fall into the La Niña phase $(1971,1973,1975$, 1988), and the remaining 14 years fall in the Neutral phase. The recharge under El Niño years ranged from 756400 acre feet $\left(\mathrm{af}_{;} 1 \mathrm{af}=1233.5 \mathrm{~m}^{3}\right)$ in 1972 to 2.003 million af in 1987, while the recharge under the La Niña years ranged from 214500 af in 1988 to 925300 af in 1971, i.e. La Niña years generally have less recharge and El Niño years have more (Fig. 2). Average January through July recharge is 324000 af during La Niña phases and 624000 af under El Niño. These recharge data were used to generate cumulative probability distributions of EA recharge for the ENSO phases (Fig. 2). The chances of receiving a January through July recharge $>600000$ af are 50.0 and $35.7 \%$ for the El Niño and Neutral phases, respectively, and $0 \%$ for the La Niña phase. Similarly, annual recharge in excess of 1 million af only occurs under the El Niño phase (frequency: $25 \%$ ) or Neutral phase $(14.3 \%)$.

\section{BENEFITS OF PREDICTION OF THE ENSO PHASE}

The EA Authority is legally required to control pumping by issuing permits, and by enacting emergency action rules in periods of low aquifer water levels. In recent history, the EA Authority has implemented pre-season dry year buyouts of irrigation water (Keplinger et al. 1998) and lawn watering bans, among other actions. The EA region also contains large municipal water supply agencies that manage water use through pricing, regulatory, and incentive 


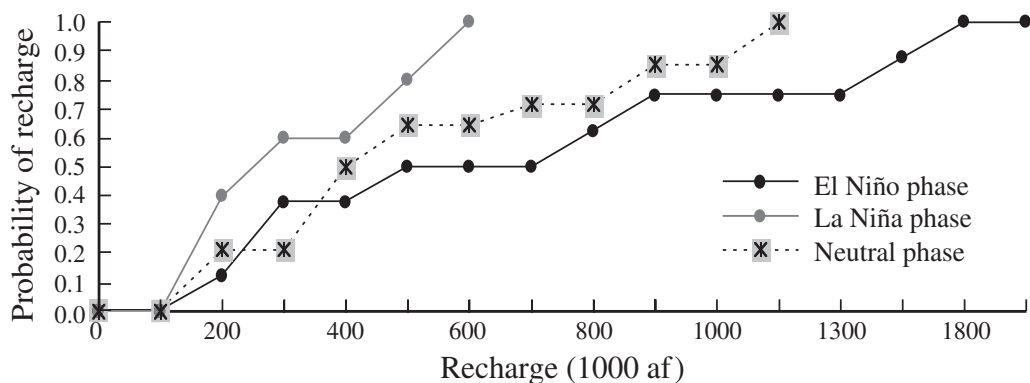

Fig. 2. Cumulative probability of Edwards Aquifer recharge for January to July, based on October determination of the ENSO phase; af: acre feet $\left(1 \mathrm{af}=1233.5 \mathrm{~m}^{3}\right)$

programs, which are again influenced by possible critical periods, as well as through long-term actions involving water leasing, water purchase, and purchase of irrigated land.

If they are given sufficient advance information (e.g. in October or November), the regional agencies could make their decisions conditional on the ENSO phase, for example by encouraging conservation or reducing water use through buyouts. The reaction to an ENSO phase announcement could also be conditional on aquifer water levels at the end of the year. For example, La Niña forecasts and low water levels portend a need to reduce water consumption. Thus, to examine regional reactions to ENSO phase information, we needed a modeling framework which can simulate reaction by including both phase information and aquifer water level.

\section{MODELING FRAMEWORK}

The basic framework we used for modeling returns and possible responses to ENSO information follows an approach used in national ENSO studies by Adams et al. (1995) and Chen \& McCarl (2000), but it is complemented by a dynamic component to account for current water levels. In this framework, we permitted different water use patterns in reaction to ENSO phase, depending upon initial water level.

The model framework couples stochastic dynamic programming (SDP) with a nonlinear programming (NLP) aquifer model. In particular, the approach is patterned after the linked SDP/NLP formulation used in McFarland (1975), Sweeney \& Tathum (1976), and Kilmer et al. (1984) as implemented for the EA by Williams (1996) and Williams et al. (2000). However, we also add ENSO phase information. In particular, the A stochastic nonlinear aquifer model was used to generate optimal pumping decisions, given ENSO phase information along with starting and ending water level, and then the SDP was used to determine optimal elevation choices (Table 1).
The values for the welfare function $g\left(\mathrm{M}_{\mathrm{et},} \mathrm{X}_{\mathrm{etr},} \mathrm{U}_{\mathrm{etr},} \mathrm{I}_{t+1, \mathrm{e}} / e_{,}, \mathrm{II}_{t}\right)$ are derived using a nonlinear aquifer model. They describe the net benefits of proceeding from an initial water level II to a final water level $\mathrm{I}_{t+1}$ when ENSO phase $e$ is forecast and recharge event $r$ occurs. The model maximizes total social welfare across municipal, industrial, and agricultural interests and across alternative ENSO phases, subject to constraints on initial and final water levels. The $g$ terms are directly drawn from the objective function.

\subsection{Nonlinear aquifer model}

The NLP aquifer model describes the aquifer in 27 weather states for the 27 years from 1970 to 1996. It is a version of the Edward Aquifer Simulation Model (EDSIM; McCarl et al. 1998) with 3 major modifications:

(1) EDSIM assumes that average final water level across the 27 states of nature (i.e. years) equals the initial water level, whereas our model is run separately under all combinations of initial and final water levels.

(2) EDSIM is run under a constraint that the crop mix chosen is the same, regardless of the state of nature, whereas our model is run with 1 and with 3 crop mixes. In particular, we develop a crop mix that must be robust given an initial and final water across all 27 states of nature, and we also develop a crop mix with respect to the El Niño, Neutral and La Niña states in the data set. This simulates decision making with and without ENSO information.

(3) The 27 states of nature are all represented in our model, but they can be separated into the El Niño, Neutral and La Niña phases with multiple events of varying strength included under each of them. This implicitly considers the possibility of improper forecasting and the possibility of events of varying strength, as discussed in Chen \& McCarl (2000). This is important, as forecasting of ENSOrelated tropical Pacific SST and its global consequences is far from perfect; ENSO extremes often emerge in boreal spring or early summer, while ENSO behavior emerges during spring and thus may not be properly foreseen in the late fall (Barnston et al. 1999; see also Mason et al. 1999, Landsea \& Knaff 2000, McPhaden 2004). On the other hand, even when El Niño or La Niña conditions occur, typical climate impacts may be absent, e.g. in the 2002-2003 El Niño. Thus decision makers are at risk when ENSO-related events do not occur as anticipated (McPhaden 2004). 
Table 1. Basic equations used in the Edwards Aquifer (EA) dynamic programming model

\begin{tabular}{|c|c|c|c|}
\hline \multicolumn{2}{|l|}{$f_{t}\left(\mathrm{II}_{t}\right)$} & $=\operatorname{MAX}_{e t}\left\{\sum_{e} \operatorname{eprob}_{e} \sum_{r / e} \operatorname{X}_{t r} \operatorname{MAX}_{t r} I_{t+1} \operatorname{prob}_{r / e}\left[g\left(\mathrm{M}_{e t}, \mathrm{X}_{e t r}, \mathrm{U}_{e t r}, \mathrm{I}_{t+1, e} / e_{r} r, \mathrm{II}_{t}\right)\right]+\beta f_{t+1}\left(\mathrm{I}_{t+1, e}\right)\right\}$ & (1) \\
\hline \multirow{5}{*}{\multicolumn{2}{|c|}{$\begin{array}{l}\mathrm{I}_{t+1, e} \\
h\left(\mathrm{M}_{e t}, \mathrm{X}_{e t r}, \mathrm{U}_{e t r}\right) \\
\mathrm{II}_{1} \\
f_{T+1}\left(\mathrm{I}_{T+1, e}\right) \\
\mathrm{I}_{t+1, e}, \mathrm{M}_{e}, \mathrm{X}_{e t r}, \mathrm{U}_{e t r}\end{array}$}} & $=w\left(\mathrm{X}_{e t r r} \mathrm{U}_{e t r r} r, e\right)$ for all $r$ and $e$ & (2) \\
\hline & & $\leq b$ for all $r$ and $e$ & (3) \\
\hline & & $=\overline{\mathrm{I}}$ & (4) \\
\hline & & $=0$ for all $r$ and $e$ & (5) \\
\hline & & $\geq 0$ for all $t, r$ & (6) \\
\hline \multicolumn{4}{|l|}{ where } \\
\hline$t$ & \multicolumn{3}{|c|}{ depicts time which runs from 1 to $T$} \\
\hline$e$ & \multicolumn{3}{|c|}{ is the ENSO phase } \\
\hline$r$ & \multicolumn{3}{|c|}{$\begin{array}{l}\text { is the recharge state of nature which is stochastic and obeys the Markovian property that current recharge is } \\
\text { independent of past recharge levels, but the probability of a recharge state } r \text { depends on the ENSO phase }\end{array}$} \\
\hline $\mathrm{II}_{t}$ & \multicolumn{3}{|c|}{ is the EA water level at the beginning of Year $t$} \\
\hline $\mathrm{I}_{t+1, e}$ & \multirow{2}{*}{\multicolumn{3}{|c|}{ is the EA water level at the end of Year $t$ under ENSO phase $e$}} \\
\hline$f_{t}\left(\mathrm{II}_{t}\right)$ & \multirow{2}{*}{\multicolumn{2}{|c|}{$\begin{array}{l}\text { is the value of the EA at Level } \mathrm{II}_{t} \\
\text { is the long run probability of ENSO phase } e\end{array}$}} & \\
\hline eprob $_{e}$ & & & \\
\hline $\operatorname{prob}_{r / e}$ & \multicolumn{3}{|c|}{ is the probability of a recharge state $r$ given an ENSO phase $e$} \\
\hline $\begin{array}{l}\mathrm{M}_{e t} \\
\mathrm{x}\end{array}$ & \multirow{2}{*}{\multicolumn{3}{|c|}{$\begin{array}{l}\text { is the agricultural crop mix chosen under ENSO phase } e \text { in Year } t \\
\text { is the agricultural land use decisions in Year } t \text { for recharge state } r \text { under ENSO phase } e\end{array}$}} \\
\hline $\begin{array}{l}\mathrm{X}_{\text {etr }} \\
\mathrm{U}_{\text {etr }}\end{array}$ & \multirow{2}{*}{\multicolumn{3}{|c|}{$\begin{array}{l}\text { is the decisions on agricultural, municipal and industrial water use in Year } t \text { for recharge state } r \text { under ENSO phase } e \\
\text { is the discount rate of currency }\end{array}$}} \\
\hline$\beta$ & & & \\
\hline
\end{tabular}

\subsection{Generation and use of the dynamic program- ming function $g$ in stochastic dynamic programming}

To generate the data for the welfare function in the SDP, the NLP model was solved for each ENSO phase under the probabilities of an occurrence of each of the 27 situations of annual recharge, as well as for a scenario lacking ENSO phase information, and then for all combinations of 12 initial (INITWAT) and final (ENDWAT) water levels varying in steps of 10 feet from 570 to 680 feet ( 173.7 to $207.3 \mathrm{~m}$ ) above sea level for the J17 reference well. This generated a final water level for each ENSO phase and strength, associated with each initial water level, with and without forecast cases. In turn, given that the SDP function was used to determine $\mathrm{I}_{t+1, s, k}$, then we could go back to the associated NLP solution and look up the crop mix, and water use patterns.

\subsection{Data}

For each of the years from 1970 to 1996, a combination of the EPIC crop simulator (Williams et al. 1989) and the Blaney-Criddle method (Heims \& Luckey 1983, Doorenbos \& Pruitt 1977) was used to develop a stationary series of climatically influenced yields and irrigation water requirements. Also, weather based shifts in water demand (Griffin \& Chang 1991) were used to adapt municipal water demand schedules to climate variation across the years.

The model was set up under 1998 demand, when Senate Bill 1477 mandated a pumping limit of 450000 af. The model was run with and without ENSO
Table 2. Model results for hydrological changes in the Edwards Aquifer (EA) over an annual period, depending on initial EA water level at Well J-17 and ENSO phase. Change with ENSO data: change compared to water flow without ENSO data (bold). Data are in $10^{3}$ acre feet (af); 1 af $=1233.5 \mathrm{~m}^{3}$

\begin{tabular}{|c|c|c|c|c|c|}
\hline \multirow{2}{*}{$\begin{array}{l}\text { Initial } \\
\text { level } \\
\text { (m) }\end{array}$} & \multirow{2}{*}{$\begin{array}{c}\text { Without } \\
\text { ENSO } \\
\text { data }\end{array}$} & \multicolumn{4}{|c|}{ Change with ENSO data } \\
\hline & & Mean & El Niño & Neutral & La Niña \\
\hline \multicolumn{6}{|c|}{ Comal Spring water flow } \\
\hline 176.7 & 0 & 0 & 0 & 0 & 0 \\
\hline 182.8 & $\mathbf{0}$ & 0 & 36 & 0 & 0 \\
\hline 188.9 & 66 & -1 & 45 & -8 & -26 \\
\hline 195.0 & 144 & -4 & 36 & -10 & -27 \\
\hline 201.1 & 209 & -1 & 45 & -8 & -26 \\
\hline \multicolumn{6}{|c|}{ San Marcos Spring water flow } \\
\hline 176.7 & 49 & -0.2 & 14 & -2 & -9 \\
\hline 182.8 & 56 & 0.8 & 14 & -1 & -9 \\
\hline 188.9 & 64 & -0.2 & 14 & -2 & -9 \\
\hline 195.0 & 72 & -0.4 & 13 & -2 & -9 \\
\hline 201.1 & 79 & -0.2 & 14 & -2 & -9 \\
\hline \multicolumn{6}{|c|}{ Agricultural water use } \\
\hline 176.7 & 136 & -18 & -24 & -20 & -7 \\
\hline 182.8 & 139 & -29 & -26 & -33 & -8 \\
\hline 188.9 & 139 & -18 & -25 & -20 & -8 \\
\hline 195.0 & 128 & -13 & -13 & -15 & -6 \\
\hline 201.1 & 140 & -17 & -26 & -18 & -7 \\
\hline \multicolumn{6}{|c|}{ Municipal and industrial water use } \\
\hline 176.7 & 303 & 1.2 & -1.8 & 0.8 & 1.7 \\
\hline 182.8 & 304 & -1.1 & 1.0 & -1.6 & 2.2 \\
\hline 188.9 & 303 & 1.4 & -1.0 & 1.0 & 2.1 \\
\hline 195.0 & 300 & 1.7 & 3.5 & 1.2 & 1.1 \\
\hline 201.1 & 303 & 1.1 & -0.2 & 0.8 & 1.9 \\
\hline \multicolumn{6}{|c|}{ Total water use } \\
\hline 176.7 & 439 & -17 & -26 & -19 & -5 \\
\hline 182.8 & 443 & -30 & -25 & -34 & -5 \\
\hline 188.9 & 442 & -17 & -26 & -19 & -6 \\
\hline 195.0 & 428 & -11 & -10 & -14 & -5 \\
\hline 201.1 & 443 & -16 & -26 & -17 & -5 \\
\hline
\end{tabular}


phase information. To test the sensitivity of the results, analysis was also done under the tighter Senate Bill, which mandates a 400000 af pumping limit. Municipal and industrial demands were held at 1998 levels throughout the $27 \mathrm{yr}$ study period, since regional water groups argue that future increase in demand will be met from alternative sources.

\subsection{Model implementation}

We focused on 2 basic questions: (1) How could ENSO phase information influence water management? (2) How much does the region gain through adaptive management versus ignoring ENSO effects?

To examine these questions we ran the model with and without ENSO phase information. The key model manipulation to permit ENSO-dependent adjustments involves the way that the states of weather nature are included. In the without-ENSO case, the crop mix is the same across all 27 years, regardless of ENSO phase. In the with-ENSO case, the model has a different crop mix for each of the ENSO phases.

\section{RESULTS}

The results of model runs with and without ENSO phase information are given in Tables $2 \& 3$. Total water use (pumping) is reduced across the board when ENSO information is included in the management of the aquifer. This occurs for 2 reasons: (1) ENSO forecasts serve to reduce water use for agriculture under all circumstances given; the ability to tailor a crop growing pattern to an ENSO phase given a November announcement reduces irrigation during the wetter El Niño events and leads to an adoption of less waterdependent crop growing patterns during the dryer La Niña and Neutral events. (2) Overall EA management reduces water use particularly in the dryer Neutral and La Niña events, with most of the adjustment coming through the agricultural sector. Year-end water levels in the EA rise with incorporation of ENSO infor-

Table 3. Model results for final water level (m) in the Edwards Aquifer over an annual period, depending on initial EA water level at Well J-17 and ENSO phase

\begin{tabular}{|c|c|c|c|c|c|}
\hline \multirow{2}{*}{$\begin{array}{l}\text { Initial } \\
\text { level (m) }\end{array}$} & \multirow{2}{*}{$\begin{array}{l}\text { Without } \\
\text { ENSO data }\end{array}$} & \multirow[b]{2}{*}{ Mean } & \multicolumn{2}{|c|}{ With ENSO data } & \multirow[b]{2}{*}{ La Niña } \\
\hline & & & El Niño & Neutral & \\
\hline 176.7 & 182.8 & 182.8 & 185.9 & 182.8 & 182.8 \\
\hline 182.8 & 185.9 & 188.9 & 188.9 & 188.9 & 185.9 \\
\hline 188.9 & 192.0 & 192.0 & 195.0 & 192.0 & 192.0 \\
\hline 195.0 & 198.1 & 198.1 & 198.1 & 198.1 & 198.1 \\
\hline 201.1 & 201.1 & 201.1 & 204.2 & 201.1 & 201.1 \\
\hline
\end{tabular}

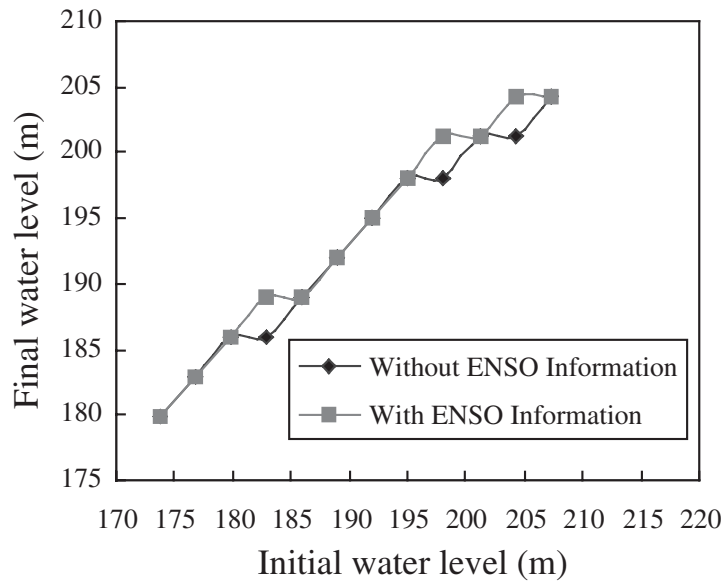

Fig. 3. Water levels in the Edwards Aquifer as a result of including or excluding ENSO data in its management

mation (Fig. 3) and spring flows are greater (Table 2). Water level increases mainly occur under the El Niño and Neutral phases with average management corresponding more to planning for La Niña and Neutral events. For example, at an initial water level of $188.9 \mathrm{~m}$, the final level is at $195.0 \mathrm{~m}$ in El Niño phases, and at $192.0 \mathrm{~m}$ in La Niña phases (Fig. 4). The level of water use does not depend strongly on initial water levels. The reduction in agricultural water use is roughly $20 \%$ for all initial water levels in the case of La Niña and Neutral phases, and about $5 \%$ in the El Niño phase.

Table 4 presents the regional economic welfare implications of using ENSO information. The welfare increase ranges from $\$ 1.1$ to $\$ 3.5$ million $\mathrm{yr}^{-1}$, depending on initial aquifer water level. Much of the welfare gain is achieved by the agricultural sector due to crop mix and water use adjustments.

For sensitivity purposes the model was also run under a 400000 af pumping limit, which is due to be attained

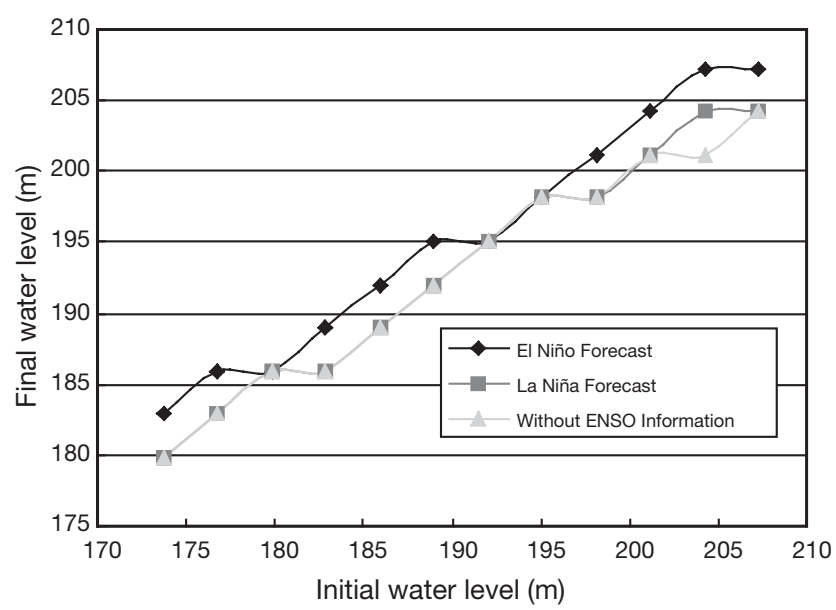

Fig. 4. Average optimal ending water-level elevations without ENSO data and with El Niño and La Niña data 
Table 4. Model results for net monetary value $\left(10^{6}\right.$ US $\left.\$\right)$ of ENSO data in management of the Edwards Aquifer (EA) over an annual period, depending on initial EA water level at Well J-17, and pumping limit (I: 450000 af; II: 400000 af; 1 af $=$ $1233.5 \mathrm{~m}^{3}$ ). Change compared to absolute value (bold) of management without ENSO data at pumping limit I

\begin{tabular}{|c|c|c|c|c|}
\hline \multirow{3}{*}{$\begin{array}{l}\text { Initial } \\
\text { level } \\
\text { (m) }\end{array}$} & \multicolumn{2}{|c|}{ Pumping limit I } & \multicolumn{2}{|c|}{ Pumping limit II } \\
\hline & Without & With & Without & With \\
\hline & ENSO & ENSO & ENSO & ENSO \\
\hline \multicolumn{5}{|c|}{ Agricultural income } \\
\hline 176.7 & 14.0 & 3.0 & -1.1 & 1.8 \\
\hline 182.8 & 14.5 & 2.6 & -1.6 & 1.5 \\
\hline 188.9 & 14.8 & 2.9 & -1.4 & 1.4 \\
\hline 195.0 & 14.7 & 3.1 & -1.1 & 1.8 \\
\hline 201.1 & 15.6 & 2.8 & -1.7 & 1.1 \\
\hline \multicolumn{5}{|c|}{ Municipal and industrial welfare } \\
\hline 176.7 & 617.0 & 0.1 & 0.1 & 0 \\
\hline 182.8 & 617.3 & 0 & -0.1 & -0.1 \\
\hline 188.9 & 617.6 & 0.1 & 0.1 & 0 \\
\hline 195.0 & 617.5 & 0.3 & 0.2 & 0.2 \\
\hline 201.1 & 618.1 & 0.1 & 0.1 & 0 \\
\hline \multicolumn{5}{|c|}{ Total welfare } \\
\hline 176.7 & 631.0 & 3.1 & -1.1 & 1.7 \\
\hline 182.8 & 631.8 & 2.6 & -1.7 & 1.3 \\
\hline 188.9 & 632.4 & 3.0 & -1.3 & 1.4 \\
\hline 195.0 & 632.1 & 3.5 & -0.9 & 2.1 \\
\hline 201.1 & 633.7 & 2.9 & -1.6 & 1.1 \\
\hline
\end{tabular}

by 2008 according to the Senate Bill 1477 (Tables 5 \& 6). Here, as in other studies (e.g. McCarl et al. 1998), the principal adjustment occurs in agriculture. Again, the use of ENSO information leads to adjustments in the agricultural sector and benefits that sector the most. In addition, water flow at Comal Springs increases and the chance of the springs going dry is reduced. Regional welfare gains are again positive, but smaller than under the 450000 af pumping limit case.

When the pumping limit is reduced to 400000 af, the use of ENSO information helps to offset losses in the agricultural sector. The value of an ENSO forecast ranges from $\$ 2.5$ million (at $182.8 \mathrm{~m}$ initial water level in the EA) to $\$ 3.5$ million (at $195.0 \mathrm{~m}$ ) under the 450000 af pumping limit, and from $\$ 1.1$ million (at $201.1 \mathrm{~m}$ ) to $\$ 2.1$ million (at $195.0 \mathrm{~m}$ ) under the 400000 af pumping limit.

\section{CONCLUSIONS}

This study investigated the regional benefits of managing water use from the Edwards Aquifer (EA) according to ENSO phase data for 1970 to 1996. ENSO information permits management adjustments worth $\$ 1.1$ to $\$ 3.5$ million, depending on EA pumping limits and initial water levels in the aquifer. Most of the water management adjustments and benefits involve shifts in agricultural crop mixes designed to exploit alterations in natural precipitation resulting from the ENSO phases. The level of water use does not strongly depend on initial water level. Reductions in agricultural water use are ca. $20 \%$ for all water levels in the La Niña and Neutral phases, and about $5 \%$ in the El Niño phase, due to wetter conditions.

Therefore, it is desirable to promote the dissemination of ENSO information to agriculture and to institute an education program on how to use this information. Nonagricultural sectors also benefit from reduced agricultural water use and increased spring flow. The exploitation of ENSO information also reduces the regional welfare loss that will result from the regional aquifer pumping reduction mandated by the legislature.

The empirical results generated using the late fall estimate of the ENSO phase may not always be perfect. The model incorporates data on multiple events under each phase that are of varying strength and thus includes the possibility of flawed estimates.

ENSO-based decision making would have been of substantial benefit in the strong 1997-1998 and subse-

Table 5. Model results for hydrological changes in the Edwards Aquifer (EA) over an annual period, depending on initial EA water level at Well J-17, and pumping limit (I: 450000 af; II: 400000 af; 1 af $=1233.5 \mathrm{~m}^{3}$ ). Change compared to absolute value (bold) of management without ENSO data at pumping limit I

\begin{tabular}{|c|c|c|c|c|}
\hline \multirow{3}{*}{$\begin{array}{l}\text { Initial } \\
\text { level } \\
\text { (m) }\end{array}$} & \multicolumn{2}{|c|}{ Pumping limit I } & \multicolumn{2}{|c|}{ Pumping limit II } \\
\hline & Without & With & Without & With \\
\hline & $\begin{array}{c}\text { ENSO } \\
\text { data }\end{array}$ & $\begin{array}{c}\text { ENSO } \\
\text { data }\end{array}$ & $\begin{array}{c}\text { ENSO } \\
\text { data }\end{array}$ & $\begin{array}{c}\text { ENSO } \\
\text { data }\end{array}$ \\
\hline \multicolumn{5}{|c|}{ Comal Spring water flow } \\
\hline 176.7 & $\mathbf{0}$ & 0 & 0 & 0 \\
\hline 182.8 & $\mathbf{0}$ & 0 & 6 & 4 \\
\hline 188.9 & 66 & -1 & 6 & 7 \\
\hline 195.0 & 144 & -4 & 5 & 3 \\
\hline 201.1 & 209 & -1 & 6 & 8 \\
\hline \multicolumn{5}{|c|}{ San Marcos Spring water flow } \\
\hline 176.7 & 49 & -0.2 & 0.3 & 0.4 \\
\hline 182.8 & 56 & 0.8 & 0.2 & 1.3 \\
\hline 188.9 & 64 & -0.2 & 0.4 & 0.5 \\
\hline 195.0 & 72 & -0.4 & 0.4 & 0.1 \\
\hline 201.1 & 79 & -0.2 & 0.4 & 0.6 \\
\hline \multicolumn{5}{|c|}{ Agricultural water use } \\
\hline 176.7 & 136 & -18 & -46 & -50 \\
\hline 182.8 & 139 & -29 & -45 & -54 \\
\hline 188.9 & 139 & -18 & -45 & -51 \\
\hline 195.0 & 128 & -13 & -33 & -40 \\
\hline 201.1 & 140 & $\mathrm{a}-17$ & -45 & -51 \\
\hline \multicolumn{5}{|c|}{ Municipal and industrial water use } \\
\hline 176.7 & 303 & 1.2 & -0.3 & -2 \\
\hline 182.8 & 304 & -1.1 & -3.0 & -4 \\
\hline 188.9 & 303 & 1.4 & -0.1 & -2 \\
\hline 195.0 & 300 & 1.7 & 0.2 & -1 \\
\hline 201.1 & 303 & 1.1 & -0.3 & -2 \\
\hline \multicolumn{5}{|c|}{ Total water use } \\
\hline 176.7 & 439 & -17 & -46 & -52 \\
\hline 182.8 & 443 & -30 & -48 & -58 \\
\hline 188.9 & 442 & -17 & -45 & -53 \\
\hline 195.0 & 428 & -11 & -33 & -41 \\
\hline 201.1 & 443 & -16 & -45 & -53 \\
\hline
\end{tabular}


Table 6. Model results for final water level (m) in the Edwards Aquifer (EA) over an annual period, depending on initial EA water level at Well J-17 and pumping limit (I: 450000 af; II: 400000 af; 1 af $=1233.5 \mathrm{~m}^{3}$ )

\begin{tabular}{|c|c|c|c|c|}
\hline \multirow{2}{*}{$\begin{array}{l}\text { Initial } \\
\text { level } \\
\text { (m) }\end{array}$} & \multicolumn{2}{|c|}{ Pumping limit I } & \multicolumn{2}{|c|}{ Pumping limit II } \\
\hline & $\begin{array}{c}\text { Without } \\
\text { ENSO } \\
\text { data }\end{array}$ & $\begin{array}{l}\text { With } \\
\text { ENSO } \\
\text { data }\end{array}$ & $\begin{array}{c}\text { Without } \\
\text { ENSO } \\
\text { data }\end{array}$ & $\begin{array}{l}\text { With } \\
\text { ENSO } \\
\text { data }\end{array}$ \\
\hline 176.7 & 182.8 & 182.8 & 182.8 & 182.8 \\
\hline 182.8 & 185.9 & 188.9 & 188.9 & 185.9 \\
\hline 188.9 & 192.0 & 192.0 & 192.0 & 195.0 \\
\hline 195.0 & 198.1 & 198.1 & 198.1 & 198.1 \\
\hline 201.1 & 201.1 & 201.1 & 201.1 & 201.1 \\
\hline
\end{tabular}

quent El Niño years. For example, in early 1997 the EA Authority spent a lot of money on a dry year option (i.e. curtailing water use and compensating farmers with cash payments) in a Neutral year and the EA later received a lot of recharge that meant the dry year option was likely unnecessary (Keplinger et al. 1998). Our dynamic programming (DP) model would have predicted that the strong 1997-1998 El Niño would yield substantial recharge and allow additional pumping, making the dry year option unnecessary. Finally, the DP results would have suggested limiting water use in the 1998-2000 La Niña years, thus avoiding some of the problems that arose due to low recharge levels and consequent low spring flows, particularly in 2000.

This study has 2 limitations: the first is related to the assumed decision maker response and degree of regional control. Our model assumes that the EA is managed by a benevolent dictator who can control all pumping, but in reality there are many potentially non-cooperative decision makers. Decision makers will be put at risk when they make preparations in anticipation of ENSO-related events, but later find that a phase is weaker than predicted, or that other phases arise (as discussed in McPhaden 2004), and this may limit cooperation. The second is that our time series is relatively short and a broader set of alternative ENSO events or a broader characterization of events would improve the forecast. Finally, it will be prudent to investigate the use of finer definitions of possible ENSO events (see Chen et al. 2002).

\section{LITERATURE CITED}

Adams RM, Bryant KJ, McCarl BA (1995) Value of improved long range weather information. Contemp Econ Pol 13:10-19

Barnston AG, Glantz MH, He Y (1999) Predictive skill of statistical and dynamical climate models in SST forecasts during 1997-98 El Niño episode and the 1998 La Niña onset. Bull Am Meteorol Soc 80:217-243

Cayan DR, Redmond KT, Riddle LG (1999) ENSO and hydrologic extremes in the western United States. J Clim 12: $2881-2893$

Chen CC, McCarl BA (2000) The value of ENSO information to agriculture: consideration of event strength and trade. J Agric Resour Econ 25:368-385

Chen CC, McCarl BA, Hill H (2002) Agricultural value of ENSO information under alternative ENSO phase. Clim Change 54:305-325

Coelho CAS, Pezzulli S, Doblas-Reyes FJ, Stephenson DB (2004) Forecast calibration and combination: a simple Bayesian approach for ENSO. J Clim 17:1504-1516

Doorenbos J, Pruitt WO (1977) Guidelines for predicting crop water requirements. Food and Agriculture Organization of the United Nations, FAO Irrigation \& Drainage Paper, FAO, Rome

Gershunov A (1998) ENSO influence on intraseasonal extreme rainfall and temperature frequencies in the contiguous United States: implications for long range predictability. J Clim 11:3192-3203

Griffin RC, Chang CC (1991) Seasonality in community water demand. West J Agric Econ 16:207-217

Heimes FJ, Luckey RR (1983) Estimating 1980 groundwater pumpage for irrigation on the high plains in parts of Colorado, Kansas, Nebraska, New Mexico, Oklahoma, South Dakota, Texas, and Wyoming. US Geological Survey, Water Resources Investigation Report 83-4123, Denver

Keplinger KO, McCarl BA, Chowdury M, Lacewell RD (1998) Economic and hydrologic implications of suspending irrigation in dry years. J Agric Resour Econ 23:191-205

Kilmer RL, Spreen T, Tilley DS (1984) A dynamic plant location model: the East Florida fresh citrus packing industry. Am J Agric Econ 65:730-737

Landsea CW, Knaff JA (2000) How much skill was there in forecasting the very strong 1997-98 El Niño? Bull Am Meteorol Soc 81:2107-2119

Longley G (1992) The subterranean aquatic ecosystem of the Balcones fault zone Edwards aquifer in Texas-threats from overpumping. In: Stanford JA, Simons JJ (eds) Proc 1st Int Conf Ground Water Ecology, Tampa, April 26-29, 1992, p 291-300

Mason SJ, Goddard L, Graham NE, Yulaeva E, Sun L, Arkin PA (1999) The IRI seasonal climate prediction system and the 1997/98 El Niño event. Bull Am Meteorol Soc 80:1853-1873

McCarl BA, Keplinger KO, Dillon C, Williams RL (1998) Limiting pumping from the Edwards aquifer: an economic investigation of proposals, water markets and springflow guarantees. Water Resour Res 35:1257-1268

McFarland J (1975) Ground water management and salinity control: a case study in Northwest Mexico. Am J Agric Econ 57:456-462

McPhaden MJ (2004) Evolution of the 2002/03 El Niño. Bull Am Meteorol Soc 85:677-695

Sweeney D, Tathum R (1976) An improved long run model of multiple warehouse location. Manag Sci 22:748-758

Williams JR, Jones CA, Canaria JR, Spaniel DA (1989) The EPIC crop growth model. Trans Am Soc Agric Engineer 32: 497-511

Williams RL (1996) Drought management and the Edwards aquifer: an economic inquiry. PhD thesis, Texas A\&M University, College Station, TX

Williams RL, McCarl BA, Chen CC (2000) Elevation dependent management of the Edwards Aquifer: a linked mathematical and dynamic programming approach. Department of Agricultural Economics, Texas A\&M University, College Station, TX

Wolter K, Dole RM, Smith CA (1999) Short-term climate extremes over the continental United States and ENSO. Part I: seasonal temperatures. J Clim 12:3255-3272

Wurbs RA (1996) Modeling and analysis of reservoir system operations. Prentice Hall, Upper Saddle River, NJ

Submitted: July 24, 2004; Accepted: December 14, 2004

Proofs received from author(s): January 28, 2005 